\title{
Analysis of the Principal's Role in Improving the Quality of Primary School Management
}

\author{
Kadariah \\ Manajemen Pendidikan Universitas Terbuka, Makassar \\ Email: kadariah@ecampus.ut.ac.id
}

(Received: September 6-2019; revised: November 15-2019; published: December 31-2019)

\begin{abstract}
This study aims to: (1) describe the principal's strategies to plan, organize, actuate, and control the school programs to improve the quality of education at SMP 1 Cilawu; and (2) describe constraints in the improvement of the quality of education. This was a case study with qualitative approach. The research subjects included teachers and educational personnel. The results of the study used the principal's as a manager: (1) plans programs by specifying the needs for teachers and educational personnel who will carry out duties, programs in the form of policies and the curriculum that will be implemented, and policies to add the time slot for the guidance and counseling subject by two hours a week; (2) makes an organizational structure by involving students'parents through the school committee and completing infrastructure facilities that the school needs; (3) gives examples of how to work well and calmly, motivation, and rewards to the personnel morally and materially, improves welfare, sends teachers and educational personnel to trainings, and motivates senior teachers to have spirit of lifelong education; and (4) controls the output, teaching and learning processes, and students from the enrolment to the graduation. (5) The constraints include the facts that there are personnel who are not disciplined, there is a lack of communication between the principal and some of the personnel, and the school operation aid funds do not match the school's needs.
\end{abstract}

Keywords: principal; planning; organizing; leading; monitoring

\section{INTRODUCTION}

Education is a human need that is very important in human life itself. Humans in essence will not only depend on nature without any other influence. In this process, the influence that will be obtained by humans from other human beings will bring a change of attitude towards the people they influence. In accordance with the above it is clear that humans need an education, education is a process to change people from certain conditions to other conditions. So with education that change will appear in the process of changing people's minds, from not understanding to understanding, from not knowing to knowing, because education is an absolute thing that must be met in an effort to improve the standard of living of humans, religion, and especially the Indonesian people not to be left behind by other nations.

This is in line with the understanding of education listed in the National Education System Law No. 20 of 2003 article 1 which reads "Education is a conscious and planned effort to create an atmosphere of learning and learning process so that students actively develop their potential to have religious spiritual strength, self-control, personality, intelligence, noble character, and the skills needed by themselves, society, nation and country ". Therefore the education system must be able to guarantee equal opportunities for improving the quality and relevance and efficiency of education management to face challenges in accordance with the 


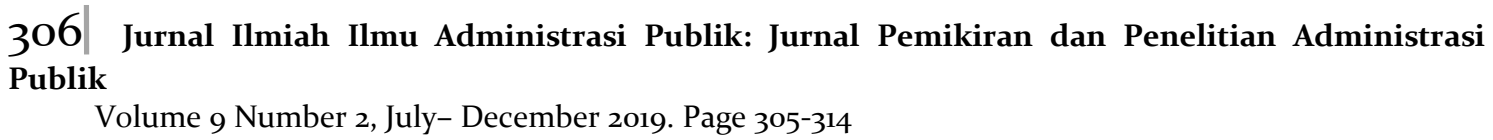

demands of changing lives at home and abroad, so that necessary changes in education are planned, directed and sustainable. Therefore education requires professional structuring, it requires capable and tough personal. From this we call education leaders / principals.

A principal is not only required to master the theory of leadership but must also be skilled at applying it to practical work situations. The principal is the head of education who has an important role in developing educational institutions, namely as the holder of control in educational institutions. In this case the role of the principal must be moved in such a way as is in his role in improving the quality of education that is as a manager so that it can influence the staff of teachers, both directly and indirectly. In addition, the principal also has a very large role in developing the quality of education in these educational institutions.

Correspondingly, the role of the principal is very influential in the growth and development of education, namely to improve human resources and the quality of education. Principals and teachers and other education personnel are required to play an active role in promoting the growth and development of the quality of their profession in the hope of gaining new knowledge. The principal also acts as an educator who is responsible for school management.

The success of an educational institution depends very much on the leadership of the principal. Because the principal as a leader in his institution, he must be able to bring his institution towards achieving the goals set, he must be able to see changes and be able to see the future in a better globalization life. The principal must be responsible for the smoothness and success of all matters of governance and formal management to his superiors or informally to the community who have entrusted their students.

The success of a school is also inseparable from an effective headmaster, while an effective headmaster shows his quality in the manner as stated by Sorenson \& Goldsmith (2008) as follows. "(1) establishes a visible presence in the school. (2) monitors teachers and students; (3) communicates a vision of school goals and objectives; (4) fosters an open and positive school culture and climate; (5) serves as an instructional expert available to faculty and staff; (6) develops a safe and orderly learning environment; (7) facilitates an instructional and curricular program that promotes student archievement; (8) establishes high organizational expectations; (9) initiates a professional development program; (10) Implements ongoing evaluation of all personed; (11) aligns curricular and strategic plans to enhance teaching and learning"

But the reality on the ground to make a quality education a lot of problems that occur principals are faced with a variety of problems that are not a few of which are in planning the principal's program sometimes lacking an active role, lack of information about professional development of educators and staff expertise, in organizing schools and monitoring the principal's program is not playing an active role.

Problems with facilities and infrastructure are also faced by schools so that the teaching and learning process is less than optimal, in monitoring and evaluation it is not right to identify the cause of the decline in the quality of education in the value of the final national exam results, the existence of educators and education personnel who lack work discipline, student delinquency included in the problem budget that is still felt to be out of balance with needs.

The role / role is a concept that cannot be separated from one's status, position and position. Between role and status are like two sides of the same coin, therefore we cannot 
understand status without role, and vice versa. Robbins (2001) defines a role as "a set of expected behavior patterns attributed to someone occupying a given position in a social unit", whereas according to (Rivai, 2004), "role or role can be interpreted as the behavior that is set and expected from someone in certain position ". Based on this understanding, it can be concluded that the role in the organizational context is behavior that must be carried out by someone based on the position, status, and certain positions held in an organization.

The principal can be defined as a functional teacher who is given the task to lead a school where teaching and learning processes are held, or where interaction occurs between the teacher giving the lesson and the student receiving the lesson (Amanda et al., 2017; Asmanurhidayani et al. ., 2018; Iskandar, 2013; Niswaty et al., 2019; Saggaf et al., 2018; Salam, 2015; Salam et al., 2018). In the explanation above, it can be concluded that the position of the principal determines the direction of an institution, the principal is the regulator of the existing program in school. Because it is expected that the principal will bring the work spirit of the teacher and build a school culture in improving the quality of education.

Gorton et al., (2006) suggested that "managers are people who do things right, are leaders all people who do the right things and good managers handle routine daily jobs". As a manager, of course, must have certain skills as Handoko (2003) stated: "(a) conceptual skills, namely the mental ability to coordinate all the interests and activities of the organization; (b) humanitarian skills, ability to work by understanding and motivating others as individuals and groups; (c) administrative skills, namely by planning, organizing, staffing and monitoring; (d) technical skills, namely the ability to use equipment, procedures, techniques from a particular field such as machinery, and so on ".

Principals as managers are essentially carrying out management functions as stated by Terry \& Rue (1987) which explains the notion of management as follows "Management is a distinc process consisting of planning, organizing, actualiting, and controlling, performed to determine and accomplish atated objectives by the use of human beings and other resources. Management is a clear process that includes planning, organizing, mobilizing and controlling that is carried out to achieve the goals set with the potential of humans and other resources. Another opinion expressed about management functions is expressed by Robbins \& Coulter (2007) that management functions include planning, organizing, leading, and controlling.

From the explanation above, the principal as a school manager organizes and manages all the potential of the school through the stages of planning, organizing, mobilizing, and supervising these potentials to support the achievement of educational goals. The formulation of the problem in this study is How do principals in planning, organizing, mobilizing, and monitoring / evaluating programs in improving the quality of elementary school management.

\section{METHOD}

This research is a case study with a qualitative approach that focuses on how the principal's role as a manager in improving the quality of elementary school management in Makassar City. Nevertheless the authors do not ignore the quantitative data needed to better describe the situation and the object of the research object (Creswell \& Creswell, 2017). A qualitative approach is used on the grounds that this research seeks to uncover the reality in the field about the role of the principal as a manager and can be understood in depth, so that in the end the research findings can be obtained.

This research was conducted at an elementary school in Makassar City. The subject of 
Volume 9 Number 2, July- December 2019. Page 305-314

this study was informants who provided information relating to the role of the principal as a manager. The subjects of this study were 11 principals, teachers, and education staff. The selection of informants in this study was obtained by snowball sampling technique. This research prioritizes data directly from informants and observations made in the field. The object of this research is the activity carried out by the principal as a manager.

The data of this study were obtained by means of researchers conducting interviews by conducting direct meetings with school principals, teachers totaling 5 people, educational staff 3 people and representatives of school committees by focusing on the material concerned with ongoing research including the curriculum being carried out at the time this, the principal's role in carrying out the tasks and history of the object under study.

This data collection method functions as a digger of information in the form of questions relating to the principal's role as a manager. In this research, documentation study was used to obtain general data about the history of 5 elementary schools in Makassar City, organizational structure, achievements, and school development plans.

In this study using the method of analysis by reducing data, display data and draw conclusions from the data collected. Data reduction is carried out by the process of selecting, loading attention to simplification or enhancement of data in the form of detailed descriptions or reports. Data reduction starts by making a summary of each data so that it is easy to understand, discarding data that is considered not important and the whole series is then grouped based on the category of the problem under study. Data display is an effort to present data by looking at the overall picture or a certain part of the research data to make it easier to read the data then the data has been reduced and then presented by combining information arranged in one form that is easily seen for review. Taking conclusions is an attempt to look for meaning to the data collected by studying patterns, themes, similarities, differences, and things that arise the most.

\section{RESULT AND DISCUSSION}

Based on the results of the analysis shows that the principal as a manager includes planning the program. In planning the program, the principal starts from: (1) planning the human resources by detailing the needs of the teaching staff who will carry out their teaching duties; (2) planning policies such as the principal's program and curriculum to be implemented in this school; (3) in formulating policies, the principal involves teachers and experts by going through several stages such as holding several meetings with PKS, teachers, school committees and other stakeholders such as supervisors; (4) Based on the principal's policy, there are additional subjects, namely guidance and counseling with 2 hours of teaching / week.

The second role of the principal is to organize the program by creating a school organizational structure such as the involvement of parents through the school committee by completing the facilities needed by the school, monitoring classroom learning, assignments such as the existence of PKS and TU according to the ability of teachers both at the level the class and the skills they have, form a committee in dealing with competitions or training.

The role of the principal as the third manager is the mobilization of the program that is by moving the existing educators and educational staff such as by giving good and calm examples in work, for teachers there is motivation for the spirit of long life education (teachers must 
learn), motivating educators and teaching staff morally and materially, improving welfare, giving awards to outstanding teachers and educators, involving teachers in education and training, MGMP, providing guidance to educators in making software (RPP, Syllabus), giving briefings as well as evaluating the performance of educators and staff education at the beginning of the month every once a month, and facilitate subordinates to be able to carry out professional development, as well as supporting educators or education personnel for those who want to continue their studies and who want to get a certification allowance.

The fourth role is monitoring and evaluation carried out by supervising both the PBM and in the achievement of improving the quality of education and the achievement of UN scores. Supervision in PBM is carried out with reference to the PKB and PKG and is carried out by a team formed by the school principal. Supervision of improving the quality of education includes supervision of inputs (HR, organizational structure, plans and programs, vision, mission and goals), processes (performance of school principals), and outputs (school achievements generated after the process both academic and non-academic achievements. Supervision is carried out regularly namely at the end of the semester, at the end / beginning of the new school year with its implementation assisted by the Vice Governor, PKS and the Coordinator of the BK (Guidance and Counseling). After supervision if there are found obstacles either from HR or sources of hope, then what is done is to give a general understanding at the teacher coaching meeting, explore the background of the problem, and find solutions to solve the problem.

The latter role is as a culture developer by implementing school culture such as culture in religion, disciplinary culture, culture of achievement and culture of cleanliness in order to improve the quality of education and form students who are characteristically and adhering to religious values.

\section{Principal in Planning Activities}

In planning a long and short term program the headmaster always calls the PKS, Vice Principal, and representatives of subject teachers to ask for their opinions and assistance in preparing a program. The long-term program of this school wants this school to become a pioneer school in the fields of sports and arts. In formulating a policy, there is a principal who helps, namely PKS in the curriculum. School committees are also involved in formulating policies relating to students and budgetary controls that are accepted by the school. School committees are active in controlling schools, this is evidenced by the frequent presence of school committees in schools and discussions with school principals and other teachers.

Changes to self-development are streamlining the type of self-development that the principal had quite a lot but at the moment is limited because too much according to the principal is less effective, self-development which is now prioritized in sports and arts, counseling guidance. In addition there is also English language training for students and the formation of students who are characterized by the way there is guidance on Friday prayers and princess activities carried out one hour before Friday prayers.

\section{Principal in Organizing Activities}

The role of the principal as an organizer in Elementary School results from parental involvement through the school committee by completing the facilities needed by the school, 
310 Jurnal Ilmiah Ilmu Administrasi Publik: Jurnal Pemikiran dan Penelitian Administrasi Publik

Volume 9 Number 2, July- December 2019. Page 305-314

monitoring learning in class, assigning tasks according to the ability of the teacher both in class and the skills they have, forming a committee in dealing with the competition.

The organizational structure in schools is seen to be in accordance with the needs because in school organizations are the prerogative rights of the principal according to the needs of the principal in carrying out their duties. During the leadership of the school principal, there is currently no recruitment of educators, especially with the current teacher certification, from the previous minimum teaching hours of 18 hours a week to 24 hours per week so to cover the amount of 24 hours per week must teach in other schools and change subjects in accordance with diploma so there is an excess of educators in certain fields of study.

\section{School Principal in Mobilization Activities}

The role of the principal as an activator in elementary school results is obtained as follows: for teachers there is a motivation for the spirit of life long education (teachers must learn), welfare improvement and the opportunity to ask questions in a pleasant atmosphere, bring in resource persons to guide teachers in making scientific writing, following seminars and others such as involving teachers in MGMP, and making effective peer tutors.

In fostering educators, school principals hold rayon-level MGMP and schools where there are 12 people each one subject in a month who are included in the MGMP level and schoollevel MGMP. Once a month a briefing is held with the teacher and with staff in order to evaluate the teacher's performance for one month. In fostering educators and education staff, school principals always hold guidance to educators and education staff in order to improve the quality of education and clarify the tasks of each, a clear example of the principal in fostering educators is by having in-house training, following the MGMP every month both at the level rayon or district, while from education staff such as at the TU and library in order to improve the performance of the teaching staff, library training is organized to make it neatly organized and students feel comfortable when reading in the library.

Welfare improvement is included in the mobilization carried out by the principal, but there are some teachers who say that financial welfare has not been hit by the targets implemented while non-financially is very good with the comfort provided by the school principal and security guarantees.

\section{School Principal in Monitoring Activities}

The role of the principal as a montor in elementary schools is through the monitoring of all planning, organizing and mobilizing, starting from supervising the making of semester programs, making lesson plans, implementing PBM both directly and indirectly (Crow \& Peterson, 2010; Lee \& Taylor, 2014). All are evaluated periodically at least at the end of the semester or in the new school year. The evaluation is assisted by PKS and other teachers who are considered capable of carrying out the task of evaluating.

In achieving the National Examination (UN) target, the principal always monitors in preparation for the UN, strategies designed for the UN can be successful, for example the principal gives motivation to students, then makes a tutoring program in the face of the UN, PBM programs on existing subjects on the UN only. The headmaster always monitors all academic activities in the school with the assistance of PKS, especially in the past two years the 
UN results at this school have declined. The school principal wants the results of the national examination this year to increase from the previous year, while the method used by the school principal is to give the task of the head teacher to hold additional hours for subjects available at the national examination so that students can better understand the subjects which will impact on grades UN results will increase.

\section{The Principal as a Cultural Developer}

In addition to the four roles carried out by the principal above, the principal has another strategy in carrying out his duties as a manager in elementary schools, the strategy is to become a cultural developer that is civilizing for discipline, accustomed to loving hygiene, cultivating achievement, and religious culture implemented with the guidance of Friday prayers and princess activities carried out at one hour before Friday prayer time. Student learning to improve student learning outcomes.

Practical Implications The results of this study provide implications for researchers with this research researchers can understand and understand the importance of the effectiveness of parental communication in developing student potential and improving student learning outcomes. Pedagogical Implications Pedagogical implications in this study are the teacher can pay attention so that students are open to the teacher if students have a problem. With the attention of the teacher, students are expected to be comfortable in attending lessons and school activities.

\section{CONCLUSION}

The role of the principal in planning the program, starting from planning the needs of human resources who will carry out tasks, planning policies in the form of the principal's program and curriculum that will be run in schools. In this plan the principal always involves the teacher, PKS and the school committee. The role of the principal in organizing the program is to create a school organizational structure that involves parents through the school committee, completing the facilities needed by the school, division of tasks such as the existence of PKS and TU according to the ability of teachers both at class level and the skills they have. In organizing the headmaster does not work alone but is assisted by the assistant headmasters and school committees.

The role of the principal in mobilizing educators and education personnel by giving good and calm examples in work, motivating educators and education staff morally and materially, improving welfare, giving rewards to personnel who excel, participating in training and education, MGMP, facilitating subordinates in carry out professional development, support educators for those who wish to continue their studies, and for senior teachers the motivation for the spirit of life long education.

The role of the principal in monitoring and evaluation which includes monitoring students from the selection process to completion, school achievements both academic and non academic, supervision of PBM with instruments referring to $\mathrm{PKG}$ and $\mathrm{PKB}$, monitoring learning in class. After monitoring, if obstacles are found in both HR and school performance, the principal gives general understanding at the teacher coaching meeting, explores the background of the problem, and seeks solutions to solve the problem. Barriers experienced by 
312 Jurnal Ilmiah Ilmu Administrasi Publik: Jurnal Pemikiran dan Penelitian Administrasi Publik Volume 9 Number 2, July- December 2019. Page 305-314

the principal in optimizing his role as a manager include: (a) work and study discipline is still lacking. (b) communication is still lacking between the principal and teachers, (c) implementing BOS funds whose rules have been determined while school needs are not in accordance with the BOS funds rules, (d) facing input coming from other stakeholders which sometimes the stakeholder wants it must be obeyed by the school.

Cultural Developers. Implementing school culture such as religious culture, disciplined culture, achievement culture, and hygiene culture in order to improve the quality of education and to form students who are characteristically and adhere to religious values.

\section{REFERENCES}

Amanda, M. O., Salam, R., \& Saggaf, S. (2017). Pengaruh Supervisi Kepala Sekolah Terhadap Kinerja Guru Di SMK Negeri 1 Bungoro Kabupaten Pangkep. Prosiding Seminar Nasional Himpunan Sarjana Ilmu-Ilmu Sosial, 2, 149-154.

Asmanurhidayani, A., Saggaf, M. S., \& Salam, R. (2018). The Effect Of Cooperation On Quality Work At Family Planning Office And Family Welfare Office In Wajo Regency.

Creswell, J. W., \& Creswell, J. D. (2017). Research design: Qualitative, quantitative, and mixed methods approaches. Sage publications.

Crow, G. M., \& Peterson, K. D. (2010). Principals Role in Restructuring Schools (P. Peterson, E. Baker, \& B. B. T.-I. E. of E. (Third E. McGaw (eds.); pp. 66-71). Elsevier. https://doi.org/https://doi.org/10.1016/B978-0-08-044894-7.00423-1

Gorton, R., Alston, J., \& Snowden, P. (2006). School Leadership and Administration: Important Concepts, Case Studies and Simulations. ERIC.

Handoko, T. H. (2003). Manajemen Edisi Kedua. BPFE. Yogyakarta.

Iskandar, U. (2013). Kepemimpinan kepala sekolah dalam peningkatan kinerja guru. Jurnal Visi Ilmu Pendidikan, 10(1).

Lee, J., \& Taylor, M. S. (2014). Dual roles in psychological contracts: When managers take both agent and principal roles. Human Resource Management Review, 24(1), 95-107. https://doi.org/https://doi.org/10.1016/j.hrmr.2013.03.001

Niswaty, R., Juniati, F., Darwis, M., Salam, R., \& Arhas, S. H. (2019). The Effectiveness of Leadership Functions Implementation in The Makassar Departement of Manpower. JPBM (Jurnal Pendidikan Bisnis Dan Manajemen), 5(1), 1-10.

Rivai, V. (2004). kiat memimpin dalam abad ke-21. PT RajaGrafindo Persada.

Robbins, S. P. (2001). Organisational behaviour: global and Southern African perspectives. Pearson South Africa.

Robbins, S. P., \& Coulter, M. (2007). Principles of management. Translated by Seyyed Mohammad Arabi and Mohammed Ali Hamid Rafiee and Behrouz Asrari Ershad, Fourth Edition, Tehran: Office of Cultural Studies. 
Saggaf, M. S., Aras, M., Akib, H., Salam, R., Baharuddin, A., \& Kasmita, M. (2018). The Quality Analysis of Academic Services Based on Importance Performance Analysis (IPA).

Salam, R. (2015). Penerapan Fungsi Administrasi Perkantoran Modern berbasis Daya Saing Organisasi dalam menyongsong MEA 2015. SEMINAR NASIONAL "Revolusi Mental Dan Kemandirian Bangsa Melalui Pendidikan Ilmu-Ilmu Sosial Dalam Menghadapi MEA 2015” Himpunan Sarjana Pendidikan Ilmu-Ilmu Sosial Indonesia, 1, 186-190.

Salam, R., Akib, H., \& Daraba, D. (2018). Utilization of Learning Media In Motivating Student Learning. 1st International Conference on Social Sciences (ICSS 2018).

Sorenson, R. D., \& Goldsmith, L. M. (2008). The principal's guide to managing school personnel. Corwin press.

Terry, G. R., \& Rue, L. W. (1987). Principios de administración. El Ateneo,. 
314 Jurnal Ilmiah Ilmu Administrasi Publik: Jurnal Pemikiran dan Penelitian Administrasi Publik Volume 9 Number 2, July- December 2019. Page 305-314 